\title{
Prevalence and Risk Factors of Anxiety among Female Governmental Secondary Schools Students in Al-madinah, Saudi Arabia
}

\author{
Awad Mohammed Al-Qahtani,, ${ }^{\star 1,2}$ Mashael B. Al-Harbi ${ }^{2}$ \\ ${ }^{1}$ Department of Family \& Community Medicine, College of Medicine, Najran University, Najran, Saudi Arabia. \\ ${ }^{2}$ Ministry of health, Postgraduate studies of family medicine in Al-Madinah Al-Munawarah, Saudi Arabia.
}

\begin{abstract}
Aim: The study aimed to measure the prevalence and risk factors of Anxiety among Female Governmental Secondary schools students, in Al-Madinah, Saudi Arabia. Methods: Cross sectional study was conducted in Al-Madinah city in 2014. Only Female secondary school students were included for study. Multistage sampling technique was used for student's inclusion. The researcher used a self-administered questionnaire containing socio-demographic data and anxiety questionnaire developed by AL-Taif Mental Health sector. 10 students were given this questionnaire as a pilot study. All data has been entered and analyzed using SPSS version 21. Results: The present study indicates the prevalence and risk factors of anxiety among female governmental secondary school students of Al-Madinah city. Overall $64.6 \%$ of students showed symptoms of anxiety. High morbid anxiety was reported among $25.5 \%$ of secondary school girls whereas high not morbid anxiety was reported among $39.1 \%$ of them. Association between students believing that school's examinations increase anxiety symptoms and anxiety was observed. Students who did not believe that anxiety symptoms increase by school's examinations reported higher rate of high morbid anxiety compared to those who believe that anxiety symptoms increase by school's examinations ( $56 \%$ versus $23.4 \%$ ). The present study did not reveal significant association between anxiety and socio-demographic characteristics of the school girls. Conclusion: The present study indicates anxiety is prevalent among secondary school girls as almost one-fourth of them reported high morbid anxiety and more than one third reported high but not morbid anxiety. Socio-demographic characteristics of the school girls were not significantly associated with anxiety.
\end{abstract}

Key words: Anxiety, Adolescents, Psychosocial disability, Secondary school students, School examinations, Stress disorder.

\section{INTRODUCTION}

Occasional anxiety is a normal part of life. A person might feel anxious when faced with a problem at work, before taking a test, or making an important decision. But anxiety disorders involve more than temporary worry or fear. For a person with an anxiety disorder, the anxiety does not go away and can get worse over time. The feelings can interfere with daily activities such as job performance, school work, and relationships. There are several different types of anxiety disorders. They include post-traumatic stress disorder, obsessive-compulsive disorder, panic disorder, social anxiety disorder and phobia. ${ }^{1}$ The exact cause of anxiety disorders is still unknown, although research has provided multiple clues. Some anxiety disorders affected by area of brain that control fear response. Anxiety disorders can run in families, so that a combination of genes and environmental stresses can produce the disorders. The role of brain chemistry is also being investigated. ${ }^{2}$
Submission Date: 30-08-2016; Revision Date: 17-11-2016; Accepted Date: 23-11-2016

DOI: 10.5530/ijper.51.1.18 Correspondence: Dr. Awad Mohammed Al-Qahtani,

Department of Family \& Community Medicine, Faculty of Medicine, Najran University, Najran, Saudi Arabia. Tel: 00966530540450 Fax: 0175417111

E-mail: awadresearch17@ gmail.com

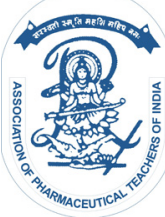

www.ijper.org 
Symptom of the anxiety can be divided into psychological and physical. Psychological symptoms of anxiety include excessive fear, restlessness, difficulty concentrating, irritability, wrong thoughts, being easily distracted whereas the physical symptoms of anxiety include autonomic and somatic symptoms such as dizziness, drowsiness and tiredness, palpitations, muscle aches and tension, dry mouth, excessive sweating, nausea, diarrhea, headache, excessive thirst, shortness of breath, abdominal discomfort, frequent urinating, insomnia and numbness and tingling sensation of the skin. ${ }^{3}$

Anxiety disorders are chronic and consider as the sixth leading cause of disability, the consequences of anxiety are associated with significant negative impact, which include poor academic performance, increased absence from school or work and loss of productivity. Anxiety can lead to increase in use of health care services, particularly primary health care.,

Significant disability in social and occupational functioning can be caused by anxiety disorders. In Canada, the impact of anxiety disorders on educational achievement was done on 201 patients meeting DSM-IV criteria for a primary anxiety disorder completed a school leaving questionnaire as well as self-report measures of anxiety, depression, and social adjustment the result is about $49 \%(\mathrm{n}=98)$ reported leaving school prematurely and $24 \%$ of those indicated that anxiety was the primary cause for this action. ${ }^{6}$ About $22 \%$ of primary care patient complain of anxiety, so one of the common mental illness attending to primary care is anxiety and is associated with high degree of severity and disability.

Many diseases e.g. anxiety and depression in adulthood have their roots in adolescence. In simple logistic models, adolescent anxiety or depressive disorders predicted an approximate 2- to 3-fold increased risk for adulthood anxiety or depressive disorders. ${ }^{8}$ In conclusion, there is an urgent need to pay more attention to the mental health of adolescent secondary school students in Saudi Arabia. Therefore, this study aimed to evaluate the extent of anxiety among female governmental secondary school in Al-Madinah City, Saudi Arabia.

\section{MATERIAL AND METHODS}

Study design: Cross sectional study. Study area: Al-Madinah city, KSA. Study conducted: Scholastic year 2014-2015. Study population: Female students of governmental secondary school. Inclusion criteria: Female students of governmental secondary school. Exclusion criteria: No exclusion criteria. Sample size: Population size-16,843 students, Expected frequency-50\%
$\%$, Worst acceptable- $60 \%$, Confidence limit- $5 \%$, Confidence interval-95\%.The calculated sample size-376.

Sampling Technique: Multi-stage random sampling technique was adopted as follows: Stage 1: Stratifying Al-Madinah city to four geographical areas (east, west, north and south) Stage 2: List all male schools in the different areas north, south, East and West. Stage 3: Selection of one school (using simple random method) from each of the four geographical areas was done. Stage 4: In each school, there are three educational levels. The researcher selected one class from every level by using simple random method. Stage 5 : By using clustering method, all the students in the selected class were included in the study.

Data collection tool and technique: The researcher used a self-administered questionnaire, consisting of two parts:

Part 1: Containing socio-demographic data: educational level and achievement, paternal and maternal education and job, family status, family income, number of brothers and sisters and ranking between them and education stress.

Part 2: The researcher used anxiety questionnaire developed by Al-Taif Mental Health sector. ${ }^{9}$

The researcher used the Arabic version scale which was validated by 25 psychiatric doctors in Taif mental health hospital. Internal consistency of the items of the scale was assured with value of Cronbach's alpha being 0.93. The questionnaire contained 47 items, and each item was scored from 1 (at no time) to 4 (all the time). Except items number $(1,25,31,35,36,37,40$, and 45$)$ were scored form 1 (all the time) to 4 (at no time). The degree from answer of the questionnaire is called crude stage. The standard degree has mean $=50, \mathrm{SD}=10$ and putting in table with crude degree. The investigator used the score given by Taif mental health hospital which states that: 1- Normal anxiety: Crude degree faces standard degree less than 60 .

2- High not morbid anxiety: Crude degree faces standard degree between 60 and less than 70 .

3- High morbid anxiety: Crude degree faces standard degree 70 or more.

Statistical analysis: Data were entered and analyzed using SPSS software, version 21. Data were presented in the form of frequency and percentage. Chi-square test was utilized to test for the association between two categorical variables. And $\mathrm{p}$ value at or less than 0.05 was used for statistical significance.

Pilot study: The researcher interviewed 10 students from outside the selected classes in order to test wording of questionnaire, feasibility of the study and to estimate 
the average time taken to finish the interview. These 10 cases were not included in main study.

Ethical Considerations: This proposal was submitted to the research ethical committee for approval. Approval letter from general supervisor of postgraduate family medicine training program in Al-Madinah was obtained. Approval letter from local research ethical community was obtained. Written consent was obtained from each participant. Permission from the general director for school at the directorate of education in Al-Madinah was obtained. Confidentiality of the information will be assured.

\section{RESULTS}

The study included 376 secondary school girls. Table 1 presents their socio-demographic characteristics. Majority of them $(92.3 \%)$ were Saudis. Students in the first school grade represent $44.1 \%$ of the participants whereas those of the third grade represent $28.5 \%$ of them. Most of them $(91 \%)$ live with their parents and only $4.2 \%$ had divorced parents. High educated (university or above) fathers and mothers were reported among $46 \%$ and $37 \%$ of the students, respectively. Students' fathers serving in Civil and military jobs were reported to be $38.8 \%$ and $34.6 \%$ respectively. Most of the mothers of the participants $(71.3 \%)$ were house wife. $60.9 \%$ of the participants had more than 5 siblings. Birth order ranged between 2 and 5 among $60.7 \%$ of the students. One third of them $(36.7 \%)$ had family income exceeding 15000 SR/month. More than half of them (54\%) got excellent in the last semester.

Prevalence of anxiety: From figure 2, high morbid anxiety was reported among $25.5 \%$ of secondary school girls whereas high not morbid anxiety was reported among $39.1 \%$ of them.

\section{Socio-demographic factors associated with high morbid anxiety:}

No statistically significant association between scholastic grade and anxiety was reported $(p=0.856)$. As shown in table 2 , high morbid anxiety was more slightly reported

\begin{tabular}{|c|c|c|c|}
\hline & Categories & Percentage & Frequency \\
\hline Nationality & $\begin{array}{c}\text { Saudi } \\
\text { Non-Saudi }\end{array}$ & $\begin{array}{c}347 \\
29\end{array}$ & $\begin{array}{l}92.3 \\
7.7\end{array}$ \\
\hline School grade & $\begin{array}{l}\text { First } \\
\text { Second } \\
\text { Third }\end{array}$ & $\begin{array}{l}166 \\
103 \\
107\end{array}$ & $\begin{array}{l}44.1 \\
27.4 \\
28.5\end{array}$ \\
\hline Living status & $\begin{array}{l}\text { With both parents } \\
\text { One or both of parents died } \\
\text { Divorced }\end{array}$ & $\begin{array}{c}342 \\
18 \\
16\end{array}$ & $\begin{array}{l}91.0 \\
4.8 \\
4.2\end{array}$ \\
\hline Fathers' education & $\begin{array}{c}\text { Illiterate } \\
\text { Primary } \\
\text { Intermediate } \\
\text { Secondary } \\
\text { University and above }\end{array}$ & $\begin{array}{c}11 \\
37 \\
50 \\
105 \\
173\end{array}$ & $\begin{array}{c}2.9 \\
9.8 \\
13.3 \\
28.0 \\
46.0\end{array}$ \\
\hline Mothers' education & $\begin{array}{c}\text { Illiterate } \\
\text { Primary } \\
\text { Intermediate } \\
\text { Secondary } \\
\text { University and above }\end{array}$ & $\begin{array}{c}24 \\
46 \\
64 \\
103 \\
139\end{array}$ & $\begin{array}{c}6.4 \\
12.2 \\
17.0 \\
27.4 \\
37.0\end{array}$ \\
\hline Fathers' Job & $\begin{array}{c}\text { Civil } \\
\text { Military } \\
\text { Business/trading }\end{array}$ & $\begin{array}{l}146 \\
130 \\
100\end{array}$ & $\begin{array}{l}38.8 \\
34.6 \\
26.6\end{array}$ \\
\hline Mothers' work status & $\begin{array}{l}\text { Yes } \\
\text { No }\end{array}$ & $\begin{array}{l}108 \\
268\end{array}$ & $\begin{array}{l}28.7 \\
71.3\end{array}$ \\
\hline Number of siblings & $\begin{array}{l}5 \geq \\
>5\end{array}$ & $\begin{array}{c}147 \\
22\end{array}$ & $\begin{array}{l}39.1 \\
60.9\end{array}$ \\
\hline Birth order & $\begin{array}{l}\text { First } \\
2-5 \\
>5\end{array}$ & $\begin{array}{c}64 \\
228 \\
84\end{array}$ & $\begin{array}{l}17.0 \\
60.7 \\
22.3\end{array}$ \\
\hline $\begin{array}{l}\text { Family income (SR/month) } \\
\qquad(\mathrm{n}=347)\end{array}$ & $\begin{array}{c}<5000 \\
5001-10000 \\
10001-15000 \\
>15000\end{array}$ & $\begin{array}{c}39 \\
109 \\
72 \\
127\end{array}$ & $\begin{array}{l}11.2 \\
31.4 \\
20.7 \\
36.7\end{array}$ \\
\hline
\end{tabular}




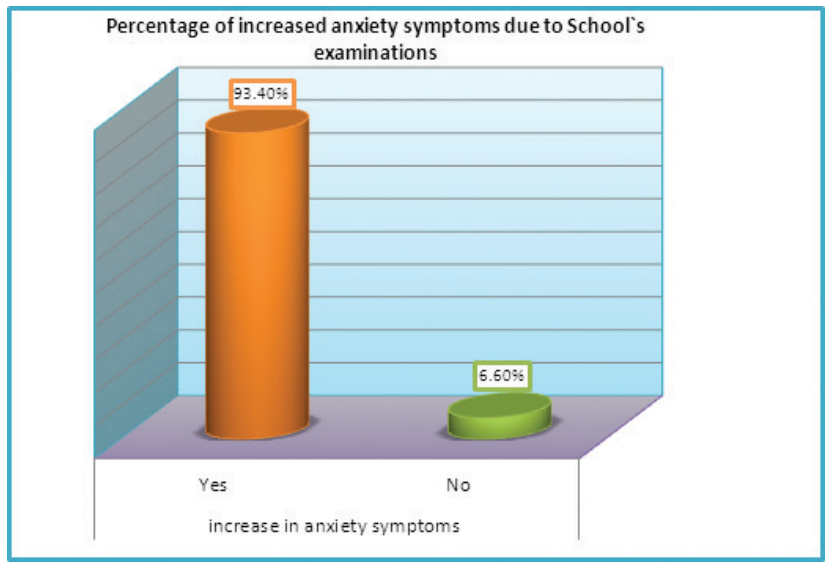

Figure 1: Percentage of increased anxiety symptoms due to School's examinations on from students' perspectives.

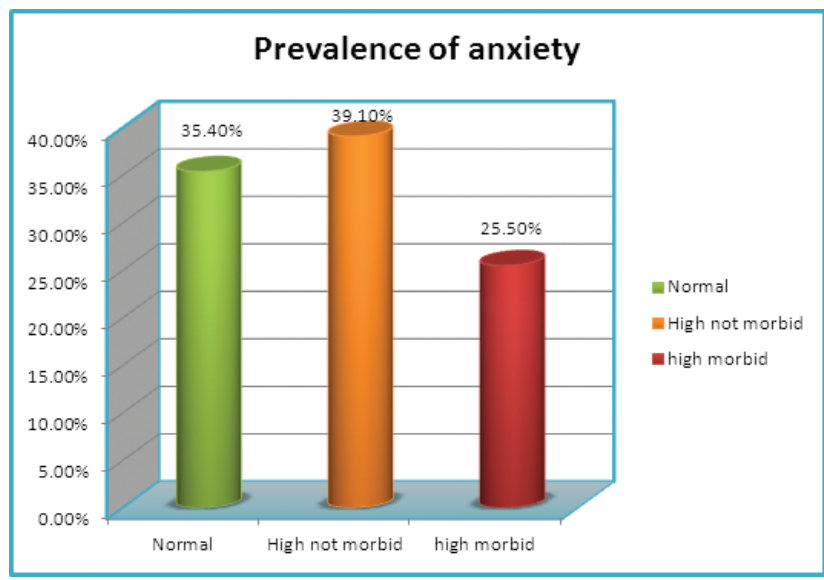

Figure 2: Prevalence of anxiety among female students enrolled in governmental secondary schools in Al-Madinah Al-Munawarah.

\begin{tabular}{|c|c|c|c|c|c|c|c|c|}
\hline \multirow[t]{2}{*}{ Variable } & \multicolumn{2}{|c|}{ Normal Anxiety } & \multicolumn{2}{|c|}{$\begin{array}{l}\text { High not morbid } \\
\text { Anxiety }\end{array}$} & \multicolumn{2}{|c|}{$\begin{array}{l}\text { High Morbid } \\
\text { Anxiety }\end{array}$} & \multirow{2}{*}{$\begin{array}{c}\text { Total } \\
\text { n (\%) }\end{array}$} & \multirow[t]{2}{*}{ p-value } \\
\hline & $\mathrm{n}$ & $(\%)$ & $\mathbf{n}$ & $(\%)$ & $\mathbf{n}$ & $(\%)$ & & \\
\hline \multicolumn{9}{|l|}{ Nationality: } \\
\hline Saudi & 124 & 35.7 & 136 & 39.2 & 87 & 25.1 & $347(100 \%)$ & \multirow{3}{*}{0.759} \\
\hline Non-Saudi & 9 & 31.0 & 11 & 38.0 & 9 & 31.0 & $29(100 \%)$ & \\
\hline Total & 133 & 35.0 & 147 & 39.0 & 96 & 26.0 & $376(100 \%)$ & \\
\hline \multicolumn{9}{|l|}{ Academic level: } \\
\hline $1^{\text {st }}$ level & 58 & 34.9 & 63 & 38.0 & 45 & 27.1 & $166(100 \%)$ & \multirow{4}{*}{0.856} \\
\hline $2^{\text {nd }}$ level & 40 & 38.8 & 40 & 38.8 & 23 & 22.4 & $103(100 \%)$ & \\
\hline $3^{\text {rd }}$ level & 35 & 32.7 & 44 & 41.1 & 28 & 26.2 & $107(100 \%)$ & \\
\hline Total & 133 & 35.0 & 147 & 39.0 & 96 & 26.0 & $376(100 \%)$ & \\
\hline \multicolumn{9}{|l|}{ Academic achievement: } \\
\hline Excellent & 70 & 34.5 & 75 & 36.9 & 58 & 28.6 & $203(100 \%)$ & \multirow{5}{*}{0.493} \\
\hline Very good & 48 & 37.2 & 54 & 41.9 & 27 & 20.9 & $129(100 \%)$ & \\
\hline Good & 15 & 38.5 & 15 & 38.5 & 9 & 23.0 & $39(100 \%)$ & \\
\hline Weak & 0 & 0.0 & 3 & 60.0 & 2 & 40.0 & $5 \quad(100 \%)$ & \\
\hline Total & 133 & 35.0 & 147 & 39.0 & 96 & 26.0 & $376(100 \%)$ & \\
\hline \multicolumn{9}{|l|}{ Living Status: } \\
\hline With both parents & 122 & 35.7 & 134 & 39.2 & 86 & 25.5 & $342(100 \%)$ & \multirow{4}{*}{0.079} \\
\hline One or both parents died & 2 & 11.1 & 10 & 55.6 & 6 & 33.3 & $18(100 \%)$ & \\
\hline Divorced & 9 & 56.2 & 3 & 18.8 & 4 & 25.0 & $16(100 \%)$ & \\
\hline Total & 133 & 35.0 & 147 & 39.0 & 96 & 26.0 & $376(100 \%)$ & \\
\hline
\end{tabular}

n- Number of students

among students of first and third grades than those of the second grade $(27.1 \%$ and $26.2 \%$ versus $22.4 \%$ ), respectively. As shown in table 2 , high morbid anxiety was more reported among non-Saudi students (31\% versus $25.1 \%$ ). However, this difference was not statistically significant $(p=0.759)$. As displayed in table 2 , students who performed weak in the last semester were more likely to develop high morbid anxiety (40\%) 
compared to others $(20.9 \%-28.6 \%)$. However, this difference was not statistically significant $(p=0.493)$. As illustrated in table 2, students whose one or both parents died were more likely to have high morbid anxiety $(33.3 \%)$ compared to those living with both parents $(25.1 \%)$. However, this difference was not statistically significant $(p=0.079)$. As shown in table 3 , high morbid anxiety was more observed among students whose fathers were university graduated compared to those whose fathers were illiterate (26\% versus $18.1 \%$ ). However, this difference was not statistically significant $(p=0.635)$. As demonstrated in table 3, high morbid anxiety was more observed among students whose mothers were secondary school graduated compared to those whose mothers were primary school graduated (31\% versus $21.7 \%)$. However, this difference was not statistically significant $(p=0.247)$. As shown in table 3, the highest rate of morbid anxiety was reported among students whose family income ranged between 10001 and $15000(26.4 \%)$ whereas the lowest rate was reported by students whose family income ranged between 5001 and 10000. However, this was not statistically significant $(p=0.838)$. As shown in table 3, students whose mothers were not working reported higher insignificant rate $(p=0.570)$ of morbid anxiety compared to those with working mothers $(26.9 \%$ versus $22.2 \%)$. As illustrated in table 4 , the highest rate of morbid anxiety was reported among students whose fathers were working in business and trading $(27 \%)$ whereas the lowest rate was reported among students whose fathers were military persons $(23.8 \%)$. However, this difference was not statistically significant $(p=0.463)$. As illustrated table 4 , morbid anxiety was more observed in students with less number of siblings $(\leq 5)$ compared to those with over 5 siblings $(26.5 \%$ versus $24.9 \%)$. This was not statistically significant $(p=0.189)$. As evident from table 4 , students with birth order over 5 reported higher rate of morbid anxiety than those of first or between second and fifth birth orders $(28.5 \%$ versus $25 \%$ and $24.6 \%$, respectively). However, this difference was not statistically significant $(p=0.176)$. As clear from table 4 , students who did not believe that anxiety symptoms increase by school`s

\begin{tabular}{|c|c|c|c|c|c|c|c|c|}
\hline \multirow[t]{2}{*}{ Variable } & \multicolumn{2}{|c|}{ Normal Anxiety } & \multicolumn{2}{|c|}{$\begin{array}{l}\text { High not } \\
\text { morbid } \\
\text { Anxiety }\end{array}$} & \multicolumn{2}{|c|}{$\begin{array}{l}\text { High Morbid } \\
\text { Anxiety }\end{array}$} & \multirow{2}{*}{$\begin{array}{l}\text { Total } \\
\text { n (\%) }\end{array}$} & \multirow[t]{2}{*}{$p$-value } \\
\hline & $\mathrm{n}$ & (\%) & $\mathrm{n}$ & (\%) & $n$ & (\%) & & \\
\hline \multicolumn{9}{|l|}{ Fathers Education: } \\
\hline Illiterate & 4 & 36.4 & 5 & 45.5 & 2 & 18.1 & $11(100 \%)$ & \multirow{6}{*}{0.635} \\
\hline Primary & 12 & 32.4 & 17 & 45.9 & 8 & 21.7 & $29(100 \%)$ & \\
\hline Intermediate & 24 & 48.0 & 14 & 28.0 & 12 & 24.0 & $50(100 \%)$ & \\
\hline Secondary & 32 & 30.5 & 44 & 41.9 & 29 & 27.6 & $105(100 \%)$ & \\
\hline University Plus & 61 & 35.3 & 67 & 38.7 & 45 & 26.0 & $173(100 \%)$ & \\
\hline Total & 133 & 35.0 & 147 & 39.0 & 96 & 26.0 & $376(100 \%)$ & \\
\hline \multicolumn{9}{|l|}{ Mothers Education: } \\
\hline Illiterate & 8 & 33.3 & 10 & 41.7 & 6 & 25.0 & $24(100 \%)$ & \multirow{6}{*}{0.247} \\
\hline Primary & 17 & 37.0 & 19 & 41.3 & 10 & 21.7 & $46(100 \%)$ & \\
\hline Intermediate & 30 & 46.9 & 20 & 31.2 & 14 & 21.9 & $64(100 \%)$ & \\
\hline Secondary & 25 & 24.3 & 46 & 44.7 & 32 & 31.0 & $103(100 \%)$ & \\
\hline University Plus & 53 & 38.1 & 52 & 37.4 & 34 & 24.5 & $139(100 \%)$ & \\
\hline Total & 133 & 35.0 & 147 & 39.0 & 96 & 26.0 & $376(100 \%)$ & \\
\hline \multicolumn{9}{|c|}{ Family Income SR/month: } \\
\hline$<5000$ & 14 & 35.9 & 15 & 38.5 & 10 & 25.6 & $39(100 \%)$ & \multirow{5}{*}{0.838} \\
\hline $5001-10000$ & 44 & 40.4 & 42 & 38.5 & 23 & 21.1 & $109(100 \%)$ & \\
\hline $10001-15000$ & 21 & 29.2 & 32 & 44.4 & 19 & 26.4 & $72(100 \%)$ & \\
\hline$>15000$ & 47 & 37.0 & 48 & 37.8 & 32 & 25.2 & $127(100 \%)$ & \\
\hline Total & 126 & 36.0 & 137 & 39.0 & 84 & 24.0 & $347(100 \%)$ & \\
\hline \multicolumn{9}{|l|}{ Mothers' work Status: } \\
\hline Working & 38 & 35.2 & 46 & 42.6 & 24 & 22.2 & $108(100 \%)$ & \multirow{3}{*}{0.570} \\
\hline $\begin{array}{l}\text { Not Working } \\
\text { (House wife) }\end{array}$ & 95 & 35.4 & 101 & 37.7 & 72 & 26.9 & $268(100 \%)$ & \\
\hline Total & 133 & 35.0 & 147 & 39.0 & 96 & 26.0 & $376(100 \%)$ & \\
\hline
\end{tabular}

n- Number of students 
Table 4: Association between different variables and anxiety among female secondary school students, Al-Madinah, Saudi Arabia

\begin{tabular}{|c|c|c|c|c|c|c|c|c|}
\hline \multirow[t]{2}{*}{ Variable } & \multicolumn{2}{|c|}{ Normal Anxiety } & \multicolumn{2}{|c|}{$\begin{array}{l}\text { High not } \\
\text { morbid } \\
\text { Anxiety }\end{array}$} & \multicolumn{2}{|c|}{$\begin{array}{l}\text { High Morbid } \\
\text { Anxiety }\end{array}$} & \multirow{2}{*}{$\begin{array}{l}\text { Total } \\
\text { n (\%) }\end{array}$} & \multirow[t]{2}{*}{ p-value } \\
\hline & $\mathbf{n}$ & $(\%)$ & $\mathbf{n}$ & $(\%)$ & $\mathbf{n}$ & $(\%)$ & & \\
\hline \multicolumn{9}{|l|}{ Fathers' Occupation: } \\
\hline $\begin{array}{c}\text { Civil } \\
\text { Military } \\
\text { Business/Trading }\end{array}$ & $\begin{array}{l}55 \\
50 \\
28\end{array}$ & $\begin{array}{l}37.7 \\
38.5 \\
28.0\end{array}$ & $\begin{array}{l}53 \\
49 \\
45\end{array}$ & $\begin{array}{l}36.3 \\
37.7 \\
45.0\end{array}$ & $\begin{array}{l}38 \\
31 \\
27\end{array}$ & $\begin{array}{l}26.0 \\
23.8 \\
27.0\end{array}$ & $\begin{array}{l}146(100 \%) \\
130(100 \%) \\
100(100 \%)\end{array}$ & \multirow{2}{*}{0.463} \\
\hline Total & 133 & 35.0 & 147 & 39.0 & 96 & 26.0 & $376(100 \%)$ & \\
\hline \multicolumn{9}{|l|}{ Number of Siblings: } \\
\hline Less than or equal to five $(\leq 5)$ & 44 & 30.0 & 64 & 43.5 & 39 & 26.5 & $147(100 \%)$ & \multirow{3}{*}{0.189} \\
\hline More than five $(>5)$ & 89 & 38.9 & 83 & 36.2 & 57 & 24.9 & $229(100 \%)$ & \\
\hline Total & 133 & 35.0 & 147 & 39.0 & 96 & 26.0 & $376(100 \%)$ & \\
\hline \multicolumn{9}{|l|}{ Birth Order: } \\
\hline First & 26 & 40.6 & 22 & 34.4 & 16 & 25.0 & $64(100 \%)$ & \multirow{4}{*}{0.176} \\
\hline $2-5$ & 72 & 31.5 & 100 & 43.9 & 56 & 24.6 & $228(100 \%)$ & \\
\hline$>5$ & 35 & 41.7 & 25 & 29.8 & 24 & 28.5 & $84(100 \%)$ & \\
\hline Total & 133 & 35.0 & 147 & 39.0 & 96 & 26.0 & $376(100 \%)$ & \\
\hline \multicolumn{9}{|c|}{ Association between school examination and anxiety: } \\
\hline Yes & 131 & 37.3 & 138 & 39.3 & 82 & 23.4 & $351(100 \%)$ & \multirow{3}{*}{$<0.001$} \\
\hline No & 2 & 8.0 & 9 & 36.0 & 14 & 56.0 & $25(100 \%)$ & \\
\hline Total & 133 & 35.0 & 147 & 39.0 & 96 & 26.0 & $376(100 \%)$ & \\
\hline
\end{tabular}

n- Number of students

examinations reported higher rate of high morbid anxiety compared to those who believe that anxiety symptoms increase by schools' examinations ( $56 \%$ versus $23.4 \%$ ). The difference was statistically significant, $\mathrm{p}<0.001$.

\section{DISCUSSION}

Anxiety is one of the most common psychological disorders in school-aged children and adolescents worldwide. ${ }^{10}$ The prevalence rates range from $4.0 \%$ to $25.0 \%$, with an average rate of $8.0 \% .{ }^{11}$ In the present study, the prevalence of high morbid anxiety among secondary school girls is very close to the upper limit reported worldwide $(25.5 \%)$. In a similar study conducted among high school students at Al-Hassa, Saudi Arabia, a prevalence of $14 \%$ has been reported. ${ }^{12}$ In an Indian study, $17.9 \%$ of girls were found to be suffering from high anxiety. ${ }^{13}$ In Canada, adolescent females reported a prevalence of psychiatric disorders $15.5 \% .{ }^{14}$ Anxiety was considered as one of the common illnesses in Hong Kong adolescents with prevalence of $20.1 \% .{ }^{15}$ However, a higher rate of $29 \%$ was reported among Vietnamese secondary school students. ${ }^{16}$

Such differences may be attributable to either the different tools used or due to socio-cultural differences and different understanding of concepts such as self-evaluation, social self-confidence and adaptive behavioral styles.
Even though variation existed, in comparison with Saudi general population, the status of anxiety symptoms among female adolescents was significantly higher $(17.3 \%)$ than those reported among general population. ${ }^{17}$ Adolescents at schools, particularly females tend to have certain personality traits that increase vulnerability to anxiety. They are conscientious and at times, develop an exaggerated sense of responsibility and finally they continually strive to be better which taken to an extreme becomes perfectionism, an impossible standard and strong driver of anxiety. ${ }^{18}$

The relationship between anxiety and academic performance has been described in previous studies conducted among adolescents. ${ }^{13,} 16,19$ This relationship has three aspects. First, anxiety interferes more with academic performance during adolescence. In a culture, like ours that judges an individual's intellectual abilities and ascribes status on the basis of academic performance, it is perhaps not surprising that students become more anxious over their academic success and failures as they age. Second, the relationship between an adolescent's academic success and anxiety is curvilinear - a minimal amount of anxiety tends to enhance academic performance, but excessive anxiety undermines academic performance. ${ }^{20}$ In accordance with that, although not statistically significant, the current study revealed that students who performed week in the last semester were 
more likely to develop high morbid anxiety compared to others. Finally, anxiety influences both learning and production in a foreign language classroom. ${ }^{21}$

In the present study, students who believed that school examination did not increase anxiety, which may indicate their carelessness towards examinations, expressed higher rate of morbidity anxiety than those who believed that examination increase their anxiety. This finding could be also explained by the fact that students with low school performance had higher rate of morbid anxiety.

In accordance to an extensive body of previous research conducted in developed countries revealing neither positive nor negative effects of maternal employment on children's development, ${ }^{22}$ the present study did not observe a relationship between mothers' work and secondary school girls' anxiety. Another research revealed that children of employed mothers often experienced favorable development outcomes and appeared to be so socially mature since employed mothers are more inclined than unemployed mothers to grant their children independence and autonomy when their youngsters are ready for it. ${ }^{23}$ In addition, when mothers have stimulating jobs, receive adequate social support from their husbands and other close associates, and are highly committed being a parent, they have generally favorable impressions of their children, rely less on power assertion to control their behavior, and are inclined to take an authoritative approach to child rearing - precisely the parenting style so often associated with favorable cognitive, social and emotional outcomes. Of course, employed mothers may be less effective parents if they are dissatisfied with their jobs, are not highly committed to being a parent, or receive little support in their parenting role. ${ }^{22,24}$

Analysis showed non-significant association for anxiety among secondary school girls with family size, birth order and number of siblings. The same findings have been reported in a similar study conducted among Kuwaiti adolescents with the exception of significant association with first birth order. ${ }^{25}$ In general, the present study did not reveal significant association between anxiety and socio-demographic characteristics of the school girls. The same has been documented in Abha in a previous study. ${ }^{26}$

Although our study is by far, the only epidemiological study investigated anxiety among secondary school girls in Al-Madinah, we acknowledge the cross-sectional design as being one of the limitations which may not point to past or future trends. Furthermore, the findings of the present study are based on self-reported information provided by students with possibility for reporting bias to have occurred because of respondents' interpretation of the questions or desire to report their emotions in a certain way or simply because of inaccuracies of responses that appear necessary to establish a definite diagnosis. Finally, it investigates anxiety among only school girls. However, this does not take away the significance of our findings and we believe that public health surveys should actively target this population, which has been neglected so far in Middle Eastern countries.

\section{CONCLUSION}

In Al-Madinah, anxiety is prevalent among secondary school girls as almost one-fourth of them reported high morbid anxiety and more than one third reported high but not morbid anxiety. Socio-demographic characteristics of the school girls were not significantly associated with anxiety. The findings of the present study highlight the need to address mental health in adolescent population, particularly females.

We recommend that primary care physicians should be alerted of the prevalence of this problem among adolescents. Efforts to improve screening must be addressed within the context of management of anxiety. Mental health promotion with adolescents' parents is essential. Further assessment is needed using standardized structured interviews to establish a definite diagnosis leading to strategies to pay attention to anxiety symptoms among students so that they might serve as an indication to take preventive action against future distress.

\section{CONFLICT OF INTEREST}

The authors declare no conflicting interest, support or funding from any Institution.

\section{ACKNOWLEDGMENT}

We thank all the participating female students of the governmental secondary schools.

\section{ABBREVIATIONS USED}

DSM-IV: Diagnostic and Statistical Manual of Mental Disorders, 4th Edition; KSA: Kingdom of Saudi Arabia; SD: Standard deviation; SR: Saudi Riyal.

\section{REFERENCES}

1. National Institutes of Health. Anxiety disoders, 2014. Available at: http://www. nimh.nih.gov/health/topics/anxiety-disorders/index.shtml.

2. American pyschatric association. Anxietydisorders, 2014. Available at: http:// www.psychiatry.org/anxiety-disorders.

3. National institute of mental health. Anxiety Disorders 2016. 
4. Baxter AJ, Vos T, Scott KM, Ferrari AJ, Whiteford HA. The global burden of anxiety disorders in 2010. Psychol Med. 2014 Jan 22;1-12. https://doi. org/10.1017/s0033291713003243.

5. Wittchen HU. Generalized anxiety disorder: prevalence, burden, and cost to society. Depress Anxiety. 2002;16(4):162-71. https://doi.org/10.1002/ da.10065 PMid:12497648.

6. Van AM, Mancini C, Farvolden P. The impactof anxiety disorders on educational achievement. J Anxiety Disord. 2003;17(5):561-71. https://doi. org/10.1016/S0887-6185(02)00228-1.

7. Weiller E, Bisserbe JC, Maier W, Lecrubier Y. Prevalence and recognition of anxiety syndromes in five European primary care settings. A report from the WHO study onPsychological Problems in General Health Care. $\mathrm{Br} \mathrm{J}$ Psychiatry Suppl. 1998;(34):18-23. PMid:9829012.

8. Pine DS, Cohen P, Gurley D, Brook J, Ma Y. The risk for early-adulthood anxiety and depressive disorders in adolescents with anxiety and depressive disorders. Arch Gen Psychiatry. 1998;55(1):56-64. https://doi.org/10.1001/ archpsyc.55.1.56 PMid:9435761.

9. Al-Delim F, Abd alsalam F, Mehani Y. Taif hospital scales series : anxiety scale. First edition. Taif : Ministry of Health. 1413;30-33.

10. Costello EJ, Mustillo S, Erkanli A, Keeler G, Angold A. Prevalence and development of psychiatric disorders in childhood and adolescence. Arch Gen Psychiatry. 2003;60(8):837-44. https://doi.org/10.1001/archpsyc.60.8.837 PMid:12912767.

11. Boyd CP, Kostanski M, Gullone E, Ollendick TH, Shek DT. Prevalence of anxiety and depression in Australian adolescents: Comparisons with worldwide data. The Journal of Genetic Psychology. 2000;161(4):479-92. https://doi.org/10.1080/00221320009596726 PMid:11117103.

12. Amr M, Amin T, El-Wasify M. Prevalence and correlates of depression and anxiety among high school students in eastern region, saudiarabia, 20th European Congress of Psychiatry European Psychiatry. 2012;27(1):468.

13. Deb S, Chatterjee $P$, Walsh K. Anxiety among high school students in India: Comparisons across gender, school type, social strata and perceptions of quality time with parents. Australian Journal of Educational \& Developmental Psychology. 2010;10:18-31

14. Romano E, Tremblay RE, Vitaro F, Zoccolillo M, Pagani L. Prevalence of psychiatric diagnoses and the role of perceived impairment: findings from an adolescent community sample. J Child Psychol Psychiatry. 2001;42(4):45161. https://doi.org/10.1111/1469-7610.00739 PMid:11383961.
15. Lau JT, Yu A, Cheung JC, Leung SS. Studies on common illnesses and medical care utilization patterns of adolescents in Hong Kong. J Adolesc Health. 2000;27(6):443-52. https://doi.org/10.1016/S1054-139X(99)00075-0.

16. Nguyen DT, Dedding C, Pham TT, Wright P, Bunders J. Depression, anxiety, and suicidal ideation among Vietnamese secondary school students and proposed solutions: a cross-sectional study. BMC Public Health. 2013;13(1):1195-99 https://doi.org/10.1186/1471-2458-13-1195 PMid:24341792 PMCid:PMC3878548.

17. Al Ansari A, Al Alaiwat B, Hamadeh R, Ali M, Mukarim B, Othman R. Treatment and Prevalence of Generalized Anxiety Disorder and Depression among Primary Care Attendees. Bahrain Medical Bulletin. 2010;32(1):1-5

18. Tylee A, Walters P. Under-recognition of Anxiety and Mood Disorders in Primary Care: Why Does the Problem Exist and What Can be Done? J Clin Psychiatry. 2007;681(2): 27-30.

19. Sarason I. The test anxiety scale. In C. Spielberger. \& I. Sarason (Eds.), Stress and Anxiety. Washington, DC: Hemisphere Press. 1980;220-41.

20. McDonald AS. The prevalence and effects of test anxiety in school children. Educational Psychology. 2001;21(1):89-101. https://doi. org/10.1080/01443410020019867.

21. Maclntyre PD, Gardner RC. Anxiety and second-language learning: Toward a theoretical clarification. Language Learning. 1989;39(2):251-75. https://doi. org/10.1111/j.1467-1770.1989.tb00423.x.

22. Greenberger E, Goldberg WA. Work, parenting, and the socialization of children. Development Psychology. 1989;25(1):22-35. https://doi. org/10.1037/0012-1649.25.1.22.

23. Hoffman LW. Effects of maternal employment in the two-parent family. American Psychologist. 1989;44(2):283-92. https://doi.org/10.1037/0003066X.44.2.283.

24. O'Neil R. Greenberger E. Patterns of commitment to work and parenting: Implications for role strain. Journal of Marriage and the Family. 1994;56:101-18. https://doi.org/10.2307/352705. 25. Abdel-Khalek AM. Age and sex differences for anxiety in relation to family size, birth order, and religiosity among Kuwaiti adolescents. Psychol Rep. 2002;90(3 Pt1):1031-6. https:// doi.org/10.2466/pr0.2002.90.3.1031 PMid:12090494.

25. Al-Gelban KS, Al-Amri HS, Mostafa OA. Prevalence of Depression, Anxiety and Stress as Measured by the Depression, Anxiety, and Stress Scale (DASS-42) among Secondary School Girls in Abha, Saudi Arabia. Sultan Qaboos Univ Med J. 2009;9(2):140-7. PMid:21509290 PMCid:PMC3074779.

\section{SUMMARY}

- Anxiety is prevalent among secondary school girls in Al-Madinah.

- Anxiety is one of the most common psychological disorders in school-aged children and adolescents worldwide.

- Adolescents at schools, particularly females tend to have certain personality traits that increase vulnerability to anxiety.

- Primary Health care physicians should be alerted of the prevalence of this problem among adolescents.

\section{About Authors}

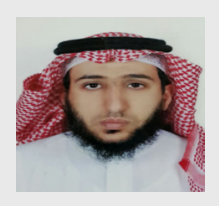

Awad Mohammed Al-Qahtani, MBBS, MD: Working as Assistant Professor and Head of Department of Family \& Community Medicine, College of Medicine, Najran University, Najran, Saudi Arabia. He is also the Vice Dean of Faculty of Nursing for Academic Affairs. Awad Mohammed Al-Qahtani has 9 paper publications in international journals. Currently, he is serving as Administrative and Finance Director at Najran University Hospital, Najran, Saudi Arabia.

Mashael B. Al-Harbi, MBBS, MD: Senior Registrar, Family Medicine, Ministry of health, Postgraduate studies of family medicine in Al-Madinah Al-Munawarah, Saudi Arabia.

Cite this article: Al-Qahtani AM, Al-Harbi MB. Prevalence and Risk Factors of Anxiety among Female Governmental Secondary Schools Students in Al-madinah, Saudi Arabia. Indian J of Pharmaceutical Education and Research. 2017;51(1):136-43. 